\title{
The Readiness of Community Based Tourism Village Development (Case Study at Bongkasa Pertiwi Tourism Village, Bali Province, Indonesia)
}

\author{
Putu Yudy Wijaya, Putu Sri Hartati, and Ni Komang Sumadi
}

\begin{abstract}
Village tourism for the benefit of the community in the development of tourism, so that people with culture are not only for tourism purposes, but are able to improve welfare and preservation. The purpose of this research is to study the readiness of the Bongkasa Pertiwi Tourism Village as a tourism village based on Community Based Tourism. There are several aspect to analyze the readiness of tourism village, i.e.: (1) Socio-economic aspects, (2) Socio-cultural aspects, (3) Environmental aspects (4) management aspects. Based on the results of an assessment of the readiness of developing the Bongkasa Pertiwi Tourism Village, the level of communitybased tourism development readiness is quite potential. Some aspects that are decisive in the readiness to develop Community Based Tourism are social and environmental aspects with sufficient potential, while the socio-economic and management aspects have potential that is not yet optimal.
\end{abstract}

Index Terms - village tourism; community based tourism; readiness; potency.

\section{INTRODUCTION}

The development of the tourism sector also has a negative impact, including the emergence of a new form of capitalism that tends to blackmail local people [1]. Increasing tourism expansion and the intervention of foreign investors in rural areas or regions have led to the process of marginalization of the socio-economic position of local communities [2].

Tourism that is not properly designed will result in (1) damage or permanent change in the physical environment; (2) damage or permanent change of historical/cultural areas and natural resources; (3) too many people and traffic jams; (4) there is pollution; and (5) traffic problems [3]. For this reason, it is necessary to realize sustainable tourism development based on democracy, efforts to diversify tourism attractions that are oriented to improving people's welfare, preservation of cultural arts and environmentally friendly tourism development [4].

The tourism village is one of the right choices to form a rural tourism area that can be used as a tourist attraction. The government encourages the development of tourism

Published on May 15, 2020.

P. Y. Wijaya is a Doctor from Faculty of Economics Business and Tourism, Hindu Indonesia University, Denpasar, Indonesia (yudywijaya333@unhi.ac.id).

P. S. Hartati is a lecturer from Faculty of Economics Business and Tourism, Hindu Indonesia University, Denpasar, Indonesia (putusrihartati59@gmail.ac.id).

N. K. Sumadi is a lecturer from Faculty of Economics Business and Tourism, Hindu Indonesia University, Denpasar, Indonesia

(komangsumadi0104@gmail.ac.id). villages to equalize development through the economic benefits of tourism The development of tourism villages aims to involve the community in the development of tourism, so that people with culture are not only objects of tourism, but are able to improve the welfare and preservation of local customary cultural values [4].

Bongkasa Pertiwi Village is a tourism village located in Abiansemal District, Badung Regency, Bali Province, Indonesia. The village has promising natural and cultural potential for tourism development. The mainstay tourist attraction in the village of Bongkasa Pertiwi is the Ayung River which is famous for its currents which is suitable for rafting. The expanse of rice fields and plantations that stretch out in almost every sub-village is a tourism attraction that is increasingly difficult to find in urban areas.

But for now, the visit and the results obtained from rural tourism activities are not in line with expectations, so it has not been able to provide welfare for local communities optimally. In addition there are also tourist villages that have not shown tourism activities such as tourist villages in general. The purpose of this study is to assess the readiness of the Bongkasa Pertiwi Tourism Village as a Community Based Tourism village.

\section{LITERATURE REVIEW}

\section{A. Rural Tourism}

Rural tourism development is a long-term and potential investment for the government as the community resources and natural resources are readily available [5]. Rural tourism is important to be developed, with consideration [6]:

1) able to accelerate rural economic development;

2) as a medium to divert or distribute economic opportunities from urban to rural areas;

3) rural tourism can accelerate: (a) economic growth, diversification and stability; (b) expansion of employment opportunities to increase income; (c) reducing the potential for migration to the city as well as the balance of population distribution; (d) repair and maintenance of public services and basic infrastructure; and (e) revitalization of the craft industry, traditions and cultural identity.

The basic criteria for the development of a tourism village include [7]:

1) the existence of objects and attractions: the village has an object of a tourist destination, at least adjacent to an object of an already well-known tourist destination, so that it can be linked to an existing travel package;

2) have physical access and market access; 
3) has potential partnerships;

4) community motivation and enthusiasm; and

5) availability of minimum public facilities. However, this criterion does not appear to be operational enough to be implemented in mapping tourist villages in Bali.

Rural tourism development should meet the following planning principles [7]:

1) pay attention to local environmental characteristics;

2) minimizing the negative impact of tourism development in the village;

3) the material used is appropriate to the local environment;

4) operational materials that are environmentally friendly and can be recycled or recycled and take into account the environmental support and carrying capacity because rural tourism is not mass tourism; and

5) involving the village community by making the village community as the perpetrators of tourism activities, namely becoming the direct/indirect owner of the tourism village and ownership of the land is not transferred.

\section{B. Village Tourism}

Village tourism involves a village with all the local resources that are owned, managed and served to the tourists [8]. Village tourism as a form of tourism, where a small group of tourists live in or near traditional life or in remote villages and study village life and the local environment [9].

Village tourism is one form of rural tourism that provides many benefits in developing existing rural resources. These various potentials can be a tourist attraction that can provide opportunities for local people to get additional income through tourism. Thus, the development of a tourism village can be one of the efforts to grow local entrepreneurial potential, diversify tourism products, sustain the economy of the local community, and revitalize local culture [7].

\section{Community Based Tourism}

Community Based Tourism (CBT) is community-based tourism, where people have authority and determinants in various aspects of tourism development itself [10]. The community is positioned as a determinant, and community involvement starts from the planning process through to its implementation.

Currently community-based tourism known as CBT (Community Based Tourism) is very popular to do in shaping a development strategy in the field of tourism. This concept has the aim to make an increase in the intensity of community participation, so that it can provide an increase in the economic field and the community has the power in making decisions to manage a development in the field of tourism.

CBT is community-based tourism, where people have authority and determinants in various aspects of tourism development itself [10]. The community is positioned as a determinant, and community involvement starts from the planning process through to its implementation.

Currently community-based tourism known as CBT is very popular to do in shaping a development strategy in the field of tourism. This concept has the aim to make an increase in the intensity of community participation, so that it can provide an increase in the economic field and the community has the power in making decisions to manage a development in the field of tourism.

There are four objectives that are desired with the enactment of the concept of community-based tourism, which are as follows.

1) Community-based tourism must contribute to improving and or improving the conservation of natural or cultural resources, including biodiversity.

2) Community-based tourism must contribute to local economic development thereby increasing income and profits for the community.

3) Community-based tourism must involve the participation of local communities.

4) Community-based tourism has a responsibility to tourists to provide products that care for the natural, social and cultural environment.

Community-based tourism must pay attention to the involvement of local communities which is an absolute requirement for the achievement of sustainable tourism development. The management must be carried out by local people whose lives and lives are affected by the development [11], so that it will lead to a community-based management system as the main actor in tourism.

\section{ReSEARCh MethodOlOgY}

The analysis technique used is the object evaluation technique and tourist attraction. The aspects assessed include: (1) Socio-economic aspects, (2) Socio-cultural aspects, (3) Environmental aspects (4) Management aspects.

The assignment of weights to each aspect of assessment is based on the Guidelines for the Analysis of Regional Operations of Objects and Nature Tourism Attraction (ADO-ODTWA) by Directorate General of Forest Protection and Nature Conservation, Ministry of Forestry of the Republic of Indonesia. The following is a calculation of the scores of each aspect of the assessment.

$S=C x W$

Where:

$\mathrm{S}=$ score or value

$\mathrm{C}=$ Sum of elements in the criteria

$\mathrm{W}=$ Weight value

After obtaining a score of each aspect of the assessment, the assessment classification is made based on the total number of readiness assessments in the development of community-based tourism using the equation:

Range $=\frac{\text { Score }_{\max }-\text { Score }_{\min }}{C}$

Where:

Range $=$ The value of the interval in establishing the classification interval of assessment

$\mathrm{C}=$ Number of classification ratings

The classification interval is ranked and divided into three classification classes, namely potential, sufficient potential and non-potential.

Socio-economic aspects include several principles namely the market, people's economy, use of local resources, selling point units, community participation in investment and profit sharing of tourism businesses. In detail, Table 1 presents the principles, criteria and assessment indicators in each of the socio-economic aspects. 
TABLE I: ASSESSMENT OF TOURISM VILLAGE READINESS IN THE SOCIO-ECONOMIC ASPECT

\begin{tabular}{|c|c|c|}
\hline No. $\quad$ Principle & Criteria & Indicator \\
\hline 1. Market & $\begin{array}{l}\text { a. Market potential/ } \\
\text { opportunity } \\
\text { b. The growth of } \\
\text { business actors }\end{array}$ & $\begin{array}{l}\text { a. The growth of the number } \\
\text { of visitors } \\
\text { b. The growth of business } \\
\text { actor }\end{array}$ \\
\hline $\begin{array}{l}\text { 2. People's } \\
\text { economy }\end{array}$ & $\begin{array}{l}\text { Economic business } \\
\text { opportunities and } \\
\text { employment } \\
\text { opportunities }\end{array}$ & $\begin{array}{l}\text { a. The growth of the number } \\
\text { of visitors } \\
\text { b. The growth of micro } \\
\text { entrepreneurship }\end{array}$ \\
\hline $\begin{array}{l}\text { 3. The use of } \\
\text { local } \\
\text { resources }\end{array}$ & $\begin{array}{l}\text { The growth of } \\
\text { community creativity }\end{array}$ & $\begin{array}{l}\text { a. Improvement of } \\
\text { facilities/infrastructure } \\
\text { b. Increased demand for } \\
\text { local resources }\end{array}$ \\
\hline $\begin{array}{l}\text { 4. Unit Selling } \\
\text { Point }\end{array}$ & $\begin{array}{l}\text { a. Branding image } \\
\text { b. Quality and worth } \\
\text { selling product }\end{array}$ & Sustainable visit \\
\hline $\begin{array}{l}\text { 5. Community } \\
\text { participation } \\
\text { in } \\
\text { investment } \\
\end{array}$ & $\begin{array}{l}\text { The existence of local } \\
\text { resources as assets }\end{array}$ & $\begin{array}{l}\text { a. Each local resource can be } \\
\text { a core value } \\
\text { b. Increased local } \\
\text { distribution flow }\end{array}$ \\
\hline $\begin{array}{ll}\text { 6. } & \text { Profit } \\
\text { Sharing }\end{array}$ & $\begin{array}{l}\text { The existence of } \\
\text { arrangements/agreemen } \\
\text { ts between parties with } \\
\text { the government }\end{array}$ & $\begin{array}{l}\text { Contribution to the benefits } \\
\text { of all parties }\end{array}$ \\
\hline
\end{tabular}

Socio-cultural aspects include several principles of preservation, appreciation and regulation. In detail, Table 2 displays the principles, criteria and indicators of assessment in each of the socio-cultural aspects.

TABLE II: ASSESSMENT OF TOURISM VILLAGE READINESS IN THE SOCIO-CULTURAL ASPECT

\begin{tabular}{|c|c|c|}
\hline No. $\quad$ Principle & Criteria & Indicator \\
\hline $\begin{array}{l}\text { 1. Preserva- } \\
\text { tion }\end{array}$ & $\begin{array}{l}\text { There are norms and } \\
\text { values }\end{array}$ & $\begin{array}{l}\text { a. The existence of norms } \\
\text { and values of local culture } \\
\text { and binding society } \\
\text { b. There is a traditional } \\
\text { ceremony that is still held }\end{array}$ \\
\hline $\begin{array}{l}\text { 2. Apprecia- } \\
\text { tion }\end{array}$ & $\begin{array}{l}\text { a. The existence of a } \\
\text { traditional ceremony } \\
\text { b. The existence of art } \\
\text { groups }\end{array}$ & $\begin{array}{l}\text { a. The existence of a } \\
\text { traditional ceremony } \\
\text { b. Number of traditional/ } \\
\text { modern art groups } \\
\text { c. The interaction of art and } \\
\text { culture }\end{array}$ \\
\hline 3. Regulation & $\begin{array}{l}\text { The existence of } \\
\text { customary regulations }\end{array}$ & $\begin{array}{l}\text { There are still customary } \\
\text { institutions }\end{array}$ \\
\hline
\end{tabular}

Environmental aspects include environmental management, conservation and environmental awareness. In detail, Table 3 presents the principles, criteria and assessment indicators for each aspect of the social environment.

TABLE III: ASSESSMENT OF TOURISM VILLAGE READINESS IN THE ENVIRONMENTAL ASPECT

\begin{tabular}{|c|c|c|}
\hline No. Principle & Criteria & Indicator \\
\hline $\begin{array}{l}\text { 1. Manage- } \\
\text { ment }\end{array}$ & $\begin{array}{l}\text { a. Village written/ } \\
\text { unwritten rules } \\
\text { b. Environmentally } \\
\text { conscious }\end{array}$ & $\begin{array}{l}\text { a. There are environmental } \\
\text { sanctions } \\
\text { b. There are still community } \\
\text { service activities } \\
\text { c. Ordered, clean, } \\
\text { comfortable, beautiful }\end{array}$ \\
\hline $\begin{array}{l}\text { 2. Conserva- } \\
\text { tion }\end{array}$ & $\begin{array}{l}\text { Sustainable use of the } \\
\text { natural and cultural } \\
\text { environment }\end{array}$ & $\begin{array}{l}\text { a. Sustainable environment } \\
\text { b. Art and culture still exist } \\
\text { c. The community still gets } \\
\text { economic value from the } \\
\text { environment }\end{array}$ \\
\hline
\end{tabular}

\begin{tabular}{lll}
$\begin{array}{l}\text { Environ- } \\
\text { mental } \\
\text { awareness }\end{array}$ & $\begin{array}{l}\text { Changes to the } \\
\text { meaning and benefits } \\
\text { of the environment are } \\
\text { increasing }\end{array}$ & $\begin{array}{l}\text { a. Increased public attention } \\
\text { and awareness of the } \\
\text { environment }\end{array}$ \\
& $\begin{array}{l}\text { b. The existence of } \\
\text { education about the } \\
\text { environment in the formal } \\
\text { and informal sectors }\end{array}$ \\
\hline
\end{tabular}

The management aspect consists of having an institution in the local community, involving all stakeholders, capacity, regulation and sustainability. In detail, Table 4 displays the principles, criteria and assessment indicators for each aspect of management.

TABLE IV: ASSESSMENT OF TOURISM VILLAGE READINESS IN THE MANAGEMENT ASPECT

\begin{tabular}{|c|c|c|}
\hline Principle & Criteria & Indicator \\
\hline $\begin{array}{l}\text { 1. Institutions in } \\
\text { the local } \\
\text { community }\end{array}$ & $\begin{array}{l}\text { Community } \\
\text { participation }\end{array}$ & $\begin{array}{l}\text { a. The existence of an active role of } \\
\text { institutions or community groups } \\
\text { b. Stakeholder involvement }\end{array}$ \\
\hline $\begin{array}{l}\text { 2. Involving all } \\
\text { stakeholders }\end{array}$ & Transparency & $\begin{array}{l}\text { a. An increasing number of people } \\
\text { are benefiting } \\
\text { b. Profit sharing mechanism } \\
\text { available } \\
\text { c. There is no public to complain }\end{array}$ \\
\hline 3. Capacity & $\begin{array}{l}\text { Capacity } \\
\text { building }\end{array}$ & $\begin{array}{l}\text { a. Knowledge and skills of } \\
\text { community groups increases } \\
\text { b. All guides are trained and obtain } \\
\text { a license (training) } \\
\text { c. Awareness of community groups } \\
\text { about conservation of natural } \\
\text { resources is increasing } \\
\text { d. Establishment of monitoring unit } \\
\text { at the community level }\end{array}$ \\
\hline 4. Regulation & Regulation & $\begin{array}{l}\text { a. Management agreement that has } \\
\text { legal legality and is recognized } \\
\text { by the community and village } \\
\text { officials } \\
\text { b. The existence of a memorandum } \\
\text { of cooperation or management } \\
\text { agreement with the owner of the } \\
\text { area } \\
\text { c. The existence code of conduct }\end{array}$ \\
\hline 5. Sustainability & Sustainability & $\begin{array}{l}\text { a. Availability of environmentally } \\
\text { friendly products } \\
\text { b. Self-finance }\end{array}$ \\
\hline
\end{tabular}

The questionnaire in this study was prepared based on indicators of aspects of the assessment of community based tourism village development readiness. The population in this study are all stakeholders associated with the development of the Bongkasa Pertiwi Village Tourism Village. The sample size is determined by 30 people, using purposive techniques, so that all stakeholders have representation.

\section{Results}

Community-based Tourism Village is a rural tourism business that involves an active role of the community. Village communities have knowledge and know the sociocultural conditions and natural resources that are potential in the local village, and selling points as a tourist attraction. Therefore, community involvement is an absolute thing to do in developing villages to become tourist attraction objects. The Community-based Tourism Village pattern recognizes the rights of local communities to manage tourism activities in their customary or management areas.

To evaluate the readiness of developing Community 
Based Tourism, it is seen based on four aspects of assessment, namely: (1) socioeconomic aspects; (2) sociocultural aspects; (3) environmental aspects; and (4) management aspects. Socio-economic aspects include several principles, namely the market, people's economy, use of local resources, selling point units, community participation in investment and profit sharing of tourism businesses. Socio-cultural aspects include several principles of preservation, appreciation and regulation. Environmental aspects include environmental management, conservation and environmental awareness. The management aspect consists of having an institution in the local community, involving all stakeholders, capacity, regulation and sustainability.

TABLE V: RESUltS OF THE ASSESSMENT OF THE DEVELOPMENT READINESS OF THE BONGKASA PERTIWI TOURISM VILLAGE

\begin{tabular}{|c|c|c|c|c|}
\hline No. & Aspect & $\begin{array}{c}\text { Sum of } \\
\text { Element }\end{array}$ & Score & Result \\
\hline 1. & Social-Economy & 70 & 420 & Not Potential \\
\hline 2. & Social-Culture & 90 & 540 & Potential Enough \\
\hline 3. & Environment & 80 & 480 & Potential Enough \\
\hline 4. & Management & 70 & 420 & Not Potential \\
\hline \multicolumn{3}{|c|}{ Mean } & 465 & Potential Enough \\
\hline
\end{tabular}

Where: 293-426=No/Not Potential; 427-560=Potential Enough; 561$694=$ Potential

Based on the results of an assessment of the readiness of developing the Bongkasa Pertiwi Tourism Village, the average value of development readiness is 465 . Based on the classification in the tourism object development effort, the Bongkasa Pertiwi Village has an assessment of communitybased tourism development readiness is quite potential. Some aspects that are determinants of Community Based Tourism readiness are socio-cultural and environmental aspects with quite potential assessment, while socioeconomic and management aspects have no potential.

\section{DisCUSSION AND CONCLUSION}

\section{A. Readiness of socio-economic aspects}

Socio-economic aspects in building the readiness to develop community-based tourism in the village of Bongkasa Pertiwi have not yet been potential to be seen in several aspects such as markets, people's economy, use of local resources, selling units, community participation in investment and profit sharing. Market opportunities become an important factor in creating economic opportunities and continuity in the development of Tourism Villages. Market growth is indicated by an increase in the number of tourist visits and growth in the number of local resource-based businesses. So that it will provide a multiplier effect in opening employment opportunities and improving the welfare of local communities. So in supporting market opportunities, it is necessary to have a branding image of tourism objects and superior products of tourist areas by increasing the optimization of local resource use. While profit sharing from tourism businesses does not yet exist directly to the community or through the Indigenous Village for religious activities.

\section{B. Readiness of social cultural aspects}

Socio-cultural and environmental aspects have considerable potential value. There are three criteria used to assess the readiness to develop a Tourism Village, namely conservation, appreciation and regulation. The preservation criteria are local cultural norms and values that bind the community, and the existence of traditional ceremonies that are still held by the people of Bongkasa Pertiwi Village is one of the efforts to preserve local culture. The criteria for appreciation are the number/types of traditional ceremonies that vary, the number of traditional/modern art groups that are adequate, as well as the frequent occurrence of art and cultural interactions between artists. This condition is one of the cultural and artistic potentials of Bongkasa Pertiwi Village. The criteria for regulating customary institutions in the Bongkasa Pertiwi Village have an important role in regulating the socio-cultural life arrangements of the community.

\section{Readiness of environmental aspects}

Environmental aspects which include environmental management, conservation, and environmental awareness. The criteria for environmental management have not been written sanctions about the existence of local environmental pollution, and only in the form of environmental service activities. In terms of conservation and environmental awareness, the still low utilization of the natural environment and culture that is sustainable to get economic value from the environment. Public attention and awareness of the environment is still limited. This is seen from the intention and means for processing environmental waste. These conditions become obstacles in the development of the Tourism Village in the Bongkasa Pertiwi Village in the future. Therefore intensification of counseling activities and training on awareness of protecting the environment is very important in building community readiness for the development of the Bongkasa Pertiwi Village as a Tourism Village.

\section{Readiness of management aspects}

The aspect of tourism management in assessing the readiness of developing community based tourism is not yet potential. This aspect includes the involvement of all stakeholders starting from the participation of social institutions in the community, the benefits obtained by the community, the mechanism of profit sharing until there are no complaints from the community. The participation of social institutions in the community starting from the community empowerment institution, tourism attraction management agency, customary villages, and government office has not yet involved active community involvement. The Tourism Village Management Institute has not been able to actively manage the Bongkasa Pertiwi tourism village, because human resources (HR) are still low, and have not yet provided optimal economic results. Creative economy is a new economic concept that relies on ideas, ideas, or creativity from human resources (HR) as the main production factor in its economic activities [12].

Other indicators in the management aspect are community capacity building in tourism management including group knowledge and skills, guiding skills, and the amount of 
training felt to be lacking. This is still an obstacle in the development of community based tourism. Therefore it is necessary to intensify training and education skills of tourism actors continuously, whose management involves the role of the community, by the community and for the community. This is because the potential for public awareness of environmental conservation is also quite high. So tourism management also needs to be supported by legality and code of conduct in each management process. So that going forward, creating community independence in managing tourist areas with products that are also environmentally friendly as well.

\section{CONCLUSION}

Based on the results of an assessment of the readiness of developing the Bongkasa Pertiwi Tourism Village, the level of community-based tourism development readiness is quite potential. Some aspects that are determinants of Community Based Tourism readiness are socio-cultural and environmental aspects with quite potential assessment, while socio-economic and management aspects have no potential.

\section{LIMITATIONS AND FUTURE RESEARCH}

This research is preliminary research related to the development of a tourist village. Furthermore, further research needs to be done on determining the key factors and analysis of development strategies that are appropriate for the development of community based tourism based villages.

\section{REFERENCES}

[1] J. Damanik, Pariwisata Indonesia (Antara Peluang dan Tantangan), Yogyakarta: Pustaka Pelajar, 2013.

[2] I G. Pitana and P. G. Gayatri, Sosiologi Pariwisata, Yogyakarta: Penerbit Andi, 2005.

[3] R. C. Mill, Tourism The International Bussiness, Jakarta: PT Grafindo Persada, 2000

[4] I N. D. Putra and I G. Pitana, Pariwisata Pro-Rakyat Meretas Jalan Mengentaskan Kemiskinan di Indonesia, Jakarta: Kementerian Kebudayaan dan Pariwisata, 2010.

[5] N. Komariah, E. Saepudin, S. Rodiah, (2018). Development of Tourist Village Based on Local Wisdom. Journal of Environmental and Management Tourism, vol.IX Issue 6(30) Fall, Available: https://doi.org/10.14505//jemt.v9.6(30).05

[6] I G. Trunajaya, "Pengembangan Pariwisata Berbasis Masyarakat di Kabupaten Badung," Penelitian Hibah Unggulan Program Studi, Fakultas Ekonomi dan Bisnis, Universitas Udayana, 2016.

[7] I K. G. Santhyasa, "Kearifan Lokal Dalam Perencanaan dan Pengembangan Spasial Desa Wisata di Bali," presented at the Seminar Nasional Agama, Adat, Seni dan Sejarah di Zaman Milenial, 2016.

[8] A. Herawati, A. Purwaningsih, Y. D. Handharko, (2018). Promoting Village Tourism through the Development of Information Systems. Review of Integrative and Economics Research, vol. 7, Supplementary Issue 1, 221-236.

[9] E. Inskeep, Tourism Planning and Integrated and Sustainable Development Approach, New York: Van Non Strand Reinhold, 1991

[10] Sugiarti and D. Argyo, Pembangunan Pariwisata Berbasis Masyarakat. Surakarta: UNS Press, 2009.

[11] I G. Pitana and I K. S. Diarta, Pengantar Ilmu Pariwisata, Yogyakarta: Penerbit Andi, 2009.

[12] M. K. S. Budhi, N. P. N. E. Lestari, N. N. R. Suasih, P. Y. Wijaya, (2020). Strategy and policies for developing SMEs based on creative economy. Management Science Letters, 10(2020). Available: DOI: 10.5267/j.msl.2020.3.005

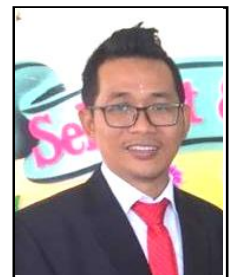

Putu Yudy Wijaya is a researcher and lecturer who was born in Gianyar Regency on March 30, 1982. He has completed his Bachelor's education at the Faculty of Economics and Business, Udayana University, Denpasar, Indonesia in 2004 in the concentration of rural development economics, Masters at Airlangga University, Surabaya, Indonesia in 2007 in the field of corporate financial management, and completed his doctoral education at Udayana University, Denpasar, Indonesia in 2019 in the field of marketing strategy management SME's. The author is also a lecturer at the Faculty of Economics, Business, and Tourism, Hindu Indonesia University, Denpasar, Indonesia, Denpasar Indonesia. Some of the work of researchers including in the field of rural economic development strategies, strategies development for SME's, and behavioral economics.

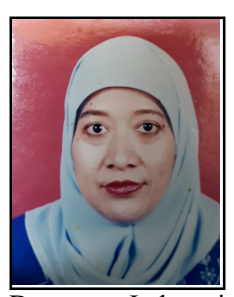

Putu Sri Hartati is a researcher and lecturer who was born in Denpasar on September 8, 1959. She completed her Bachelor's education at the Faculty of Arts, Udayana University, Denpasar, Indonesia in 1985 in anthropology, Masters at the UNIKNAS University, Denpasar Indonesia in 2006 in the field of marketing management science for SME's. The author is also a lecturer at the Faculty of Economics, Business, and Tourism, Hindu Indonesia University, Denpasar, Indonesia. Research expertise in the field of marketing behavior strategies and cultural anthropology.

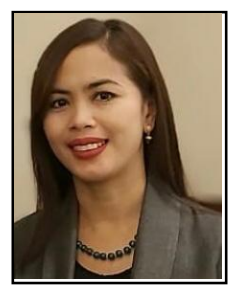

Ni Komang Sumadi is a researcher and lecturer who was born in Klungkung Regency on 1April 1980. She has completed her Bachelor's degree in the Faculty of Economics and Business, Udayana University, Denpasar, Indonesia in 2003 in the field of financial accounting, Master in Udayana University, Denpasar Indonesia in 2008 in the field of rural development economics. The author is also a lecturer at the Faculty of Economics, Business, and Tourism, Hindu Indonesia University, Denpasar, Indonesia. Research expertise in the field of behavioral accounting, statistics, community empowerment economics. 